研究課題別研究評価

1. 研究課題名:

遺伝子探索ベクターの開発とその応用

2. 研究者名:

相垣敏郎

3. 研究のねらい:

ショウジョウバエの遺伝子探索システムを使って, 寿命を制御する遺伝子の構造と機能を解明す る.

4. 研究結果:

1）老化や寿命決定機構に関する突然変異体は極めて少なく, その分子機構の解明を阻んでいる. 化 学物質や放射線，あるいはトランスポゾンの挿入によって得られる変異体は主に機能破壊変異で あり, 発生過程に障害があらわれるものもあるため, 長寿命変異体を得ることは困難であった. さき がけ研究で開発した遺伝子探索システムを利用して, 長寿命変異体の同定を試みた. 飼育温度に よってGAL4 の発現を制御できるhs-GAL4 系統を利用して，成体期に強制発現を誘導することによ り，寿命を延長する作用をもつ遺伝子を探索した. hs-GAL4 系統をGS 系統に交配したF1世代を通 常の飼育温度 $\left(25^{\circ} \mathrm{C}\right)$ で発生させたあと, 成体をやや高い温度 $\left(30^{\circ} \mathrm{C}\right)$ で飼育することによって緩やか な強制発現を誘導し, その寿命を測定した. これにより, 強制発現された遺伝子の効果を老化過程 に限定して検定することが可能となった.

2）スクリーニングの結果，強制発現によって寿命を延長する作用を有する遺伝子6個を同定した. こ れらのうち 3 遺伝子は強制発現によりパラコ一ト(活性酸素産生剂)に対する耐性を示し, 酸化スト レスと老化や寿命の決定機構の密接な関連を示唆した(原著論文2参照).

3）寿命決定機構とストレス耐性の関係をより具体的に明らかにすることを目的として, 候補遺伝子の 中でショウジョウバエの新規遺伝子 DPOSH (Drosophila Plenty of SH3s) 遺伝子について, 構造と 機能の解析をおこなった. マウスやヒトPOSHに見られる4個の SH3ドメイン, および N 末端のリン グフインガードメインはよく保存されていたが, Rac1 結合ドメインの配列は存在しなかった. その発 現は卵細胞に見られるほか, 成虫の翅や脚原基でも低いレベルで発現が認められた. DPOSH を 神経細胞で特異的に発現させたところ, $25^{\circ}$ C における成虫寿命が対照群に比べて $14 \%$ 延長され た(原著論文1参照). このことは, 熱ショックプロモータ一を用いて $30^{\circ}$ C のストレス環境下で行った 前回の実験結果とよく一致した. 同時に, 神経系での発現が十分な寿命延長効果をもつことが明 らかになった. また, DPOSH を発生過程で強制発現すると, DPOSH は細胞死を引き起こすことが わかった. そこで, 細胞死に関与する JNK/SAPK カスケードの関与を検討したところ, JNK/SAPK の標的である puckard 遺伝子が活性化がおこり, また同カスケードで働く遺伝子の突然変異体で は, DPOSH の強制発現の効果が抑制されることが判明した(原著論文1参照). これらのことは, DPOSH の強制発現による寿命の延長は JNK カスケードの低レベルの活性化によっておこったも のと推察される.

5. 自己評価:

当初のさきがけ研究の 3 年間で作成した GS 系統をさらに 2 年間維持することができたのが大きい. 寿命決定遺伝子のスクリーニングと同定した遺伝子の解析を行うことができた. 老化研究の歴史は 古いが, いまだに老化のしくみの解明にはいたっていない. 今回確立した新しい方法を使って長寿 命遺伝子をに探索することにより, 寿命や老化機構に大きくせまることができるものと考えている. 
現在文部科学省特定ゲノムの支援をうけて, 合計2万系統を目指した大規模な系統作成計画が進 行中である. 今回の研究は長寿命遺伝子に注目したが, 機能獲得変異体が得られることを利用し た様々なスクリーニングが可能である. 基礎研究者だけでなく, 製薬企業からも注目されている. 今 後, 作成した系統の長期にわたる維持と, 国内外への分譲体制をうまくととのえる必要がある.

6. 領域総括の見解:

相垣君は広く遺伝研究に用いられているショウジョウバエを利用し、遺伝子の探索を計画した。非 常にユニークな所は、強制発現系による探索法開発を目指したことで、この方法はさきがけの3年 間でほぼ完成され、多くの遺伝形質を探り出し、国際的にも認められるようになった。多くの系は国 内外に広く分与され、使用されるようになったが、自らは寿命決定機構の研究を目指して、更に研 究を進めた。

大学院生のみを相手の小規模研究室で、2年間の延長をしたが、この間にすでに特定研究領域や、 ミレニアムプロジェクトに招かれるなど、従来よりの研究成果が認められると共に、寿命に関しても 多くの変異体を分離し、寿命延長関連の遺伝子解析を進めるなど十分な成果が得られた。今後更 なる発展を期待する。

\section{7. 主な論文等:}

(特許、受賞、招待講演等)

原著論文

1. Seong, K.-H., Matsuo, T., Fuyama, Y. and Aigaki, T. (2001) Neural specific overexpression of DPOSH, Drosophila Plenty of SH3s, extends the longevity of adult flies. Biogerontology (in press)

2. Seong, K.-H., Ogashiwa, T., Matsuo, T., Fuyama, Y. and Aigaki, T. (2001) Application of the gene search system to a screen for longevity gene in Drosophila. Biogerontology 2:209-217

3. Aigaki, T., Ohsako, T., Toba, G., Seong, K.-H. and Matsuo, T. (2001) The gene search system: its application to functional genomics and a screen for longevity genes in Drosophila melanogaster. J. Neurogenet. (in press)

4. Ejima, A., Nakayama, S. and Aigaki, T. (2001) Phenotypic association of spontaneous ovulation and sexual receptivity in virgin females of Drosophila melanogaster Behavior Genetics Vol. 31, No. 5, 437-444

5. Toba, G. and Aigaki, T. (2000): Disruption of the Microsomal glutathione S-transferase-like gene reduces life span of Drosophila melanogaster. Gene 253, 179-187.

6. 相垣敏郎(2001): 老化促進遺伝子と老化抑制遺伝子. Dimentia Japan, 15, 56-63

7. 相垣敏郎 (2001) ポストゲノムの神経科学一ショウジョウバエの研究からー. 脳の科学 23, 59-63.

8. 相垣敏郎(2001)ショウジョウバエゲノムの機能解析. 蛋白質·核酸·酵素(印刷中)

特許

名称: ジーンサーチシステムを用いた長寿命遺伝子の探索法, および同定した遺伝子 